\title{
Modelling of Grassed Road Divider as Bio-Retention System for Urban Road Drainage
}

\author{
Darrien Yau Seng Mah", ${ }^{\mathrm{a},}$, Amy Ee Ling Wong ${ }^{\mathrm{a}}$ and Fang Yenn Teo ${ }^{\mathrm{b}}$ \\ ${ }^{a}$ Department of Civil Engineering, Faculty of Engineering, Universiti Malaysia Sarawak \\ ${ }^{b}$ Faculty of Engineering, Nottingham University Malaysia
}

\begin{abstract}
An evaluation on the applicability of bio-retention system in grassed road divider under the high rainfall of equatorial region was conducted by developing computer-aided stormwater models using USEPA SWMM 5.1. The models simulated road runoffs with and without bio-retention system. A single unit of the bio-retention system tested here was $3 \mathrm{~m}$ in width, $6 \mathrm{~m}$ in length with $150 \mathrm{~mm}$ of ponding depth and $600 \mathrm{~mm}$ of soil/storage depth. The results indicated that soil types of loamy sand, sandy loam and loam showed similar performances in reducing runoff. With the installation of bio-retention system, road runoff could be reduced by 40-50\% when subjected to 60 minutes of 2-, 5- and 10-year ARI rain events. The results obtained from the simulation were encouraging, and indicated that bio-retention system in grassed road divider could function to augment the existing urban road drainage.
\end{abstract}

Keywords: Infiltration, Rain garden, Road, Runoff, Stormwater, Urban.

\section{Introduction}

Grassed road divider is always treated as temporary road reserve which separates the road for opposite lanes. Sooner or later, it is to be removed for widening of roads. Generally, the awareness is low in Malaysia on using grassed road divider as a medium of natural system to adsorb stormwater. Diverting stormwater from the road into the grassed road divider would make the divider an useful component on roads, thus creating green pocket in urban road drainage system. Therefore, an attempt is made here to investigate the suitability of grassed road divider as bio-retention system subjected to high rainfall of equatorial region.

Conventional road drainage system (see Figure 1) carries stormwater runoff through a network of underground pipelines and urban drains [1]. This approach has shown its limitation over the years. One of the disadvantages using the conventional road drainage system is the higher risk of flooding when heavy rain occurs [2-3]. Stormwater gathers at the tarred road surfaces are disposed of rapidly to the network of pipelines and drains. At times, overwhelming volumes of stormwater generated from increasing tarred road surfaces in cities could cause congestion at parts of the mentioned drainage network. Flash flooding could follow. To combat the mentioned congestion, portions of stormwater could be directed elsewhere to slow down the stormwater being flushed down the pipelines and drains.

\footnotetext{
* Corresponding author. Tel.: +60-082-581039; Fax: +60-082-581155

E-mail address: ysmah@unimas.my

Manuscript History:

Received 30 July, 2018, Revised 15 September, 2018, Accepted 16 September, 2018, Published 30 September, 2018
} 


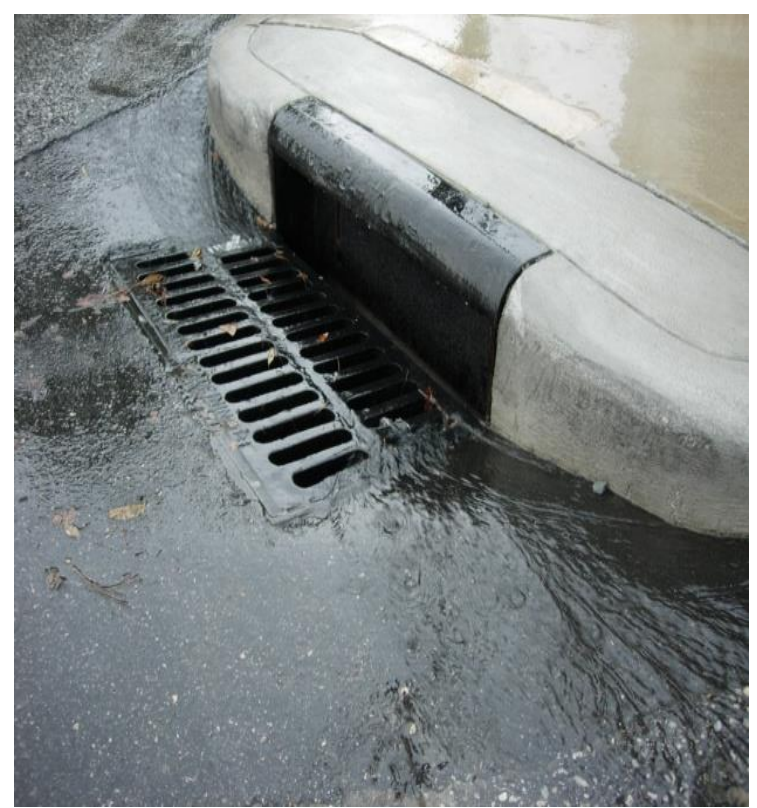

Figure 1. Conventional road drainage system [4]

Bio-retention system is one of the ways that could function to slow down stormwater runoff and temporary trap the water for infiltration through the designed soil layers before it is discharged into the urban drain [5-6]. Application of bio-retention system on existing areas aims to create more attractive view on urban landscape that are commonly applied to small areas [7]. Bio-retention systems are usually located around building, along highway and road drainage swales, adjacent to parking lots, and within landscape areas in impervious or high-density environment (see Figure 2). Bio-retention systems are also applied at area which the activities carried out produce runoff with high concentration of contaminant compared to those normally found in stormwater [8-9].
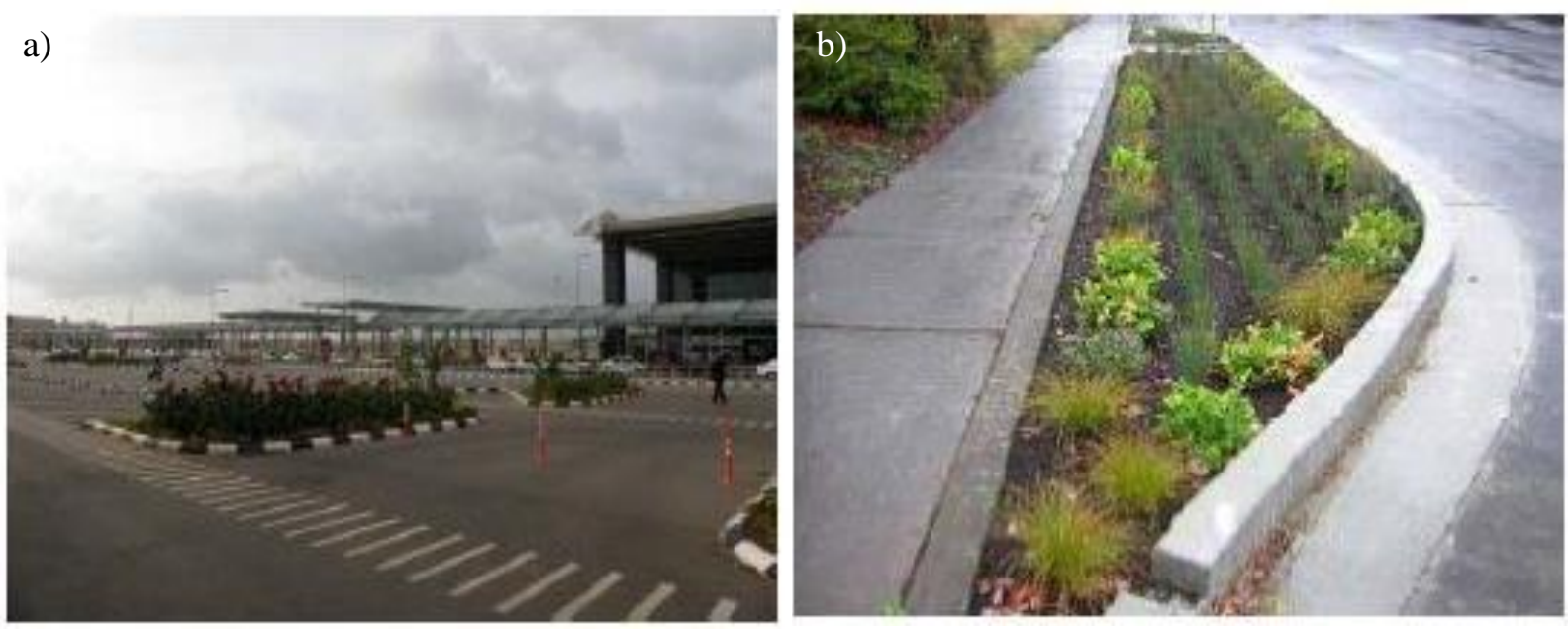

Figure 2. Typical bio-retention applications for a) parking lot and b) roadside planter box [8]

Bio-retention systems are common in the west, but not so in Malaysia. Awareness of bio-retention systems as stormwater component is therefore low, and most people has a narrow perception that greenery along roads is for landscape or aesthetics only [10]. On road, grassed road divider is the most suitable component to be modified for stormwater management. 
These systems use a layer of high permeable soil to promote stormwater infiltration while filtering and retaining pollutants (see Figure 3). The ponding area provides a storage space for stormwater and more time for the infiltration of captured stormwater. Woody and herbaceous native vegetations that can survive under drought and flood conditions are planted in the systems to promote pollutant cycling. The bio-retention soil media is generally covered by a layer of mulch to support vegetative growth and to capture particle-type pollutants.

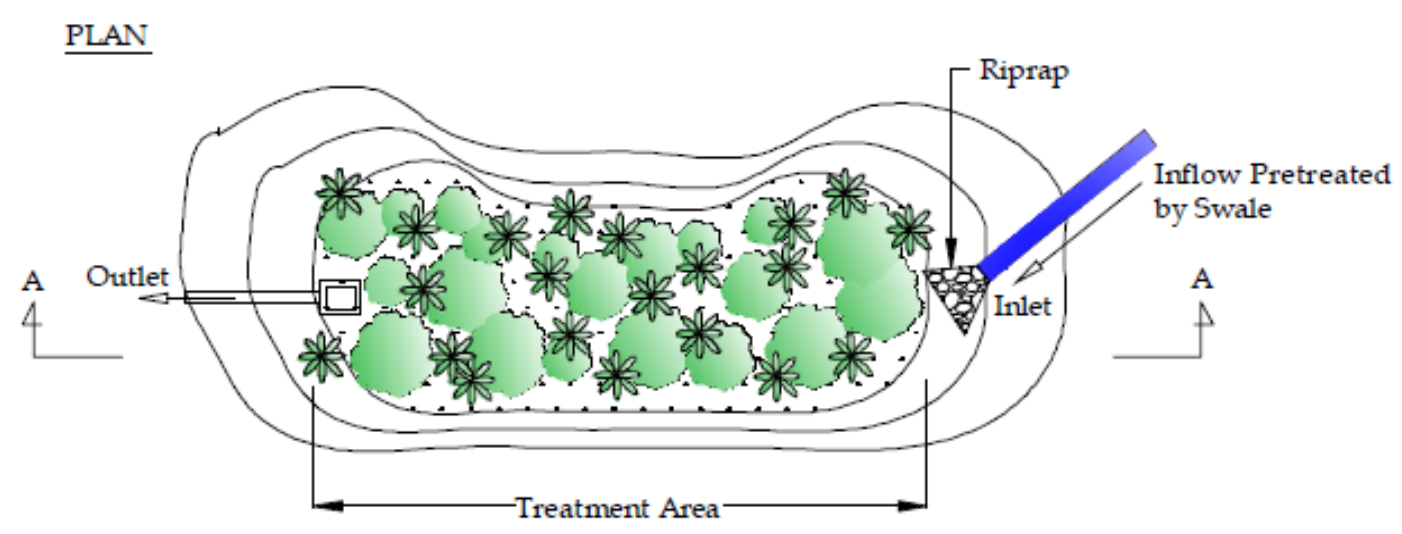

SECTIONA-A

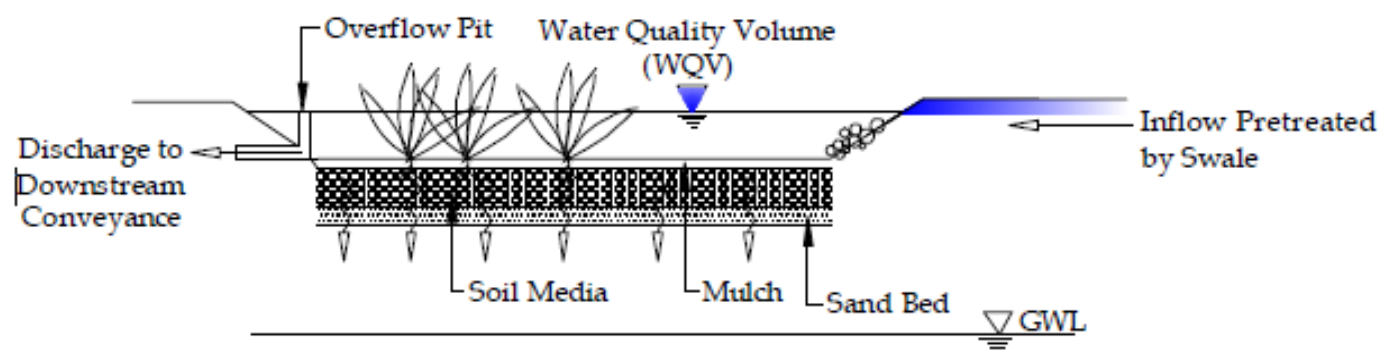

Figure 3. Permeable bio-retention system and associated flows [8]

\section{Materials and methods}

\subsection{Case study}

Road divider is important to prevent any accident happened involving vehicles coming from opposite way [11]. It can be constructed using masonry structure, fence, guardrail or concrete wall. Figure 4 below shows one of the typical road dividers in Kuching City, Sarawak, Malaysia.

A survey was done on the grassed road dividers to obtain an average dimension of road divider. Twenty-three roads with road dividers scattered around Kuching were selected, in which the length and width of road divider on those roads were measured. Figure 5 shows the plotting of graph for the length and width of surveyed road dividers in Kuching. From the graph, the dimensions obtained are mostly $500 \mathrm{~m}$ to $1150 \mathrm{~m}$ in length and $3 \mathrm{~m}$ to $4 \mathrm{~m}$ in width, in which the range is encased in a dotted line box. Within the mentioned range, a stretch of grassed road divider ( $3 \mathrm{~m}$ wide and $1119 \mathrm{~m} \mathrm{long}$ ) located at Sherip Masahor Road was chosen for case study to represent a common road divider in Kuching. 


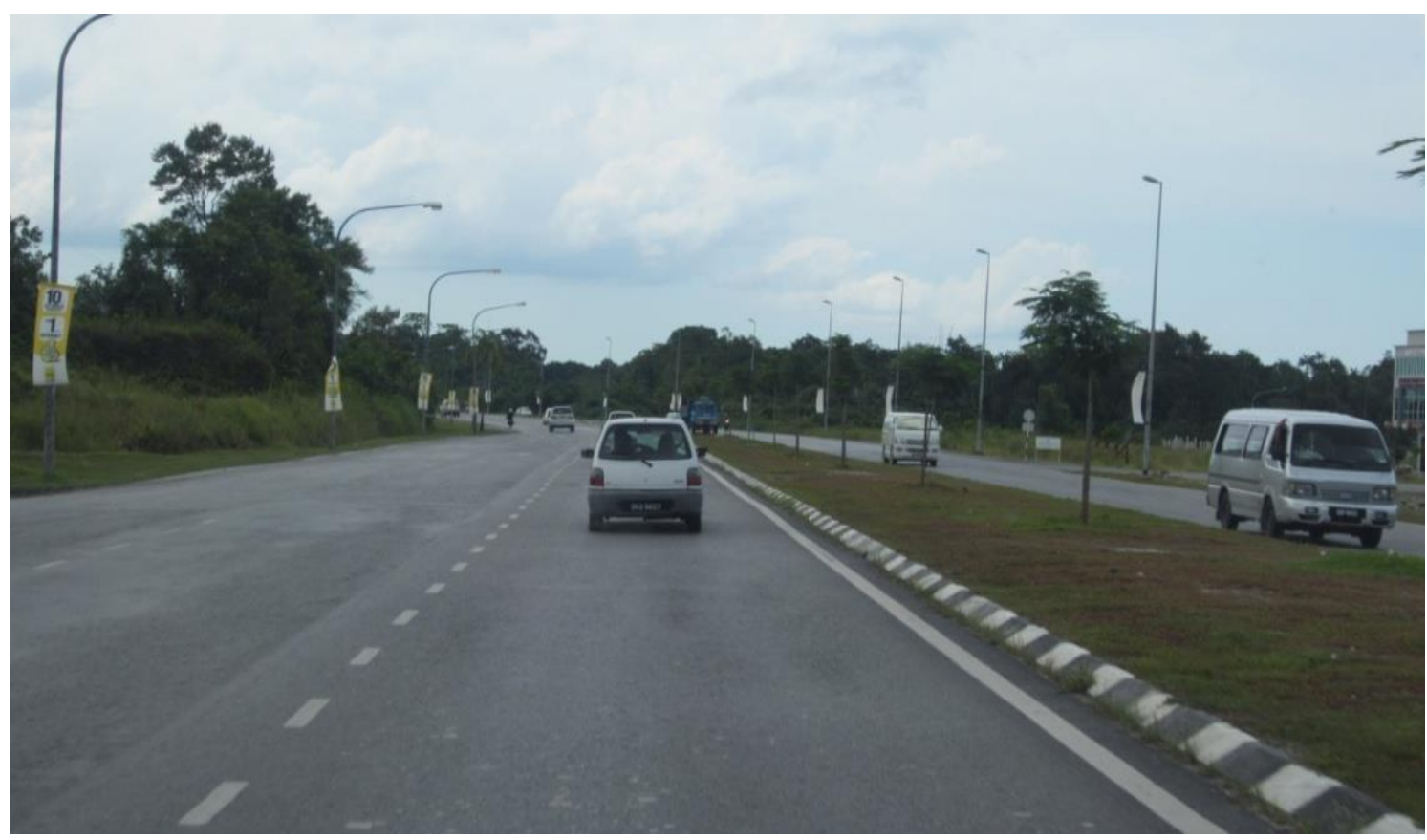

Figure 4. Grassed Road Divider in Kuching City

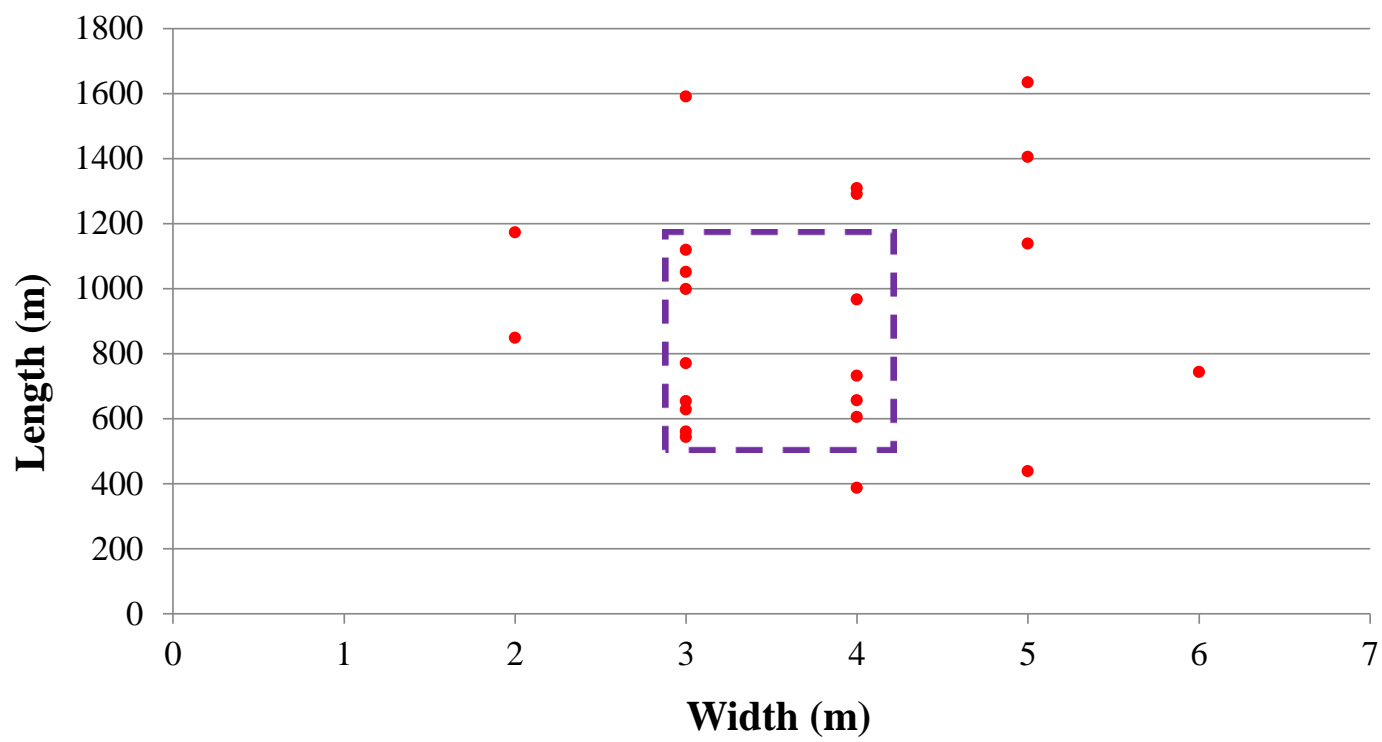

Figure 5. Surveyed Length and Width of Grassed Road Dividers in Kuching

The area had been developed into housing areas and commercial centres (see Figure 6). Having a case study allowed site conditions to be measured and collected. Site conditions like the road surface area, road gutter, existing roadside drain, drain slope, its direction of flow and stormwater outlets could be identified and measured. A realistic bio-retention system could then be represented in a digital platform so that a virtual grassed road divider could be tested as a stormwater management method to control stormwater runoff at that area. 


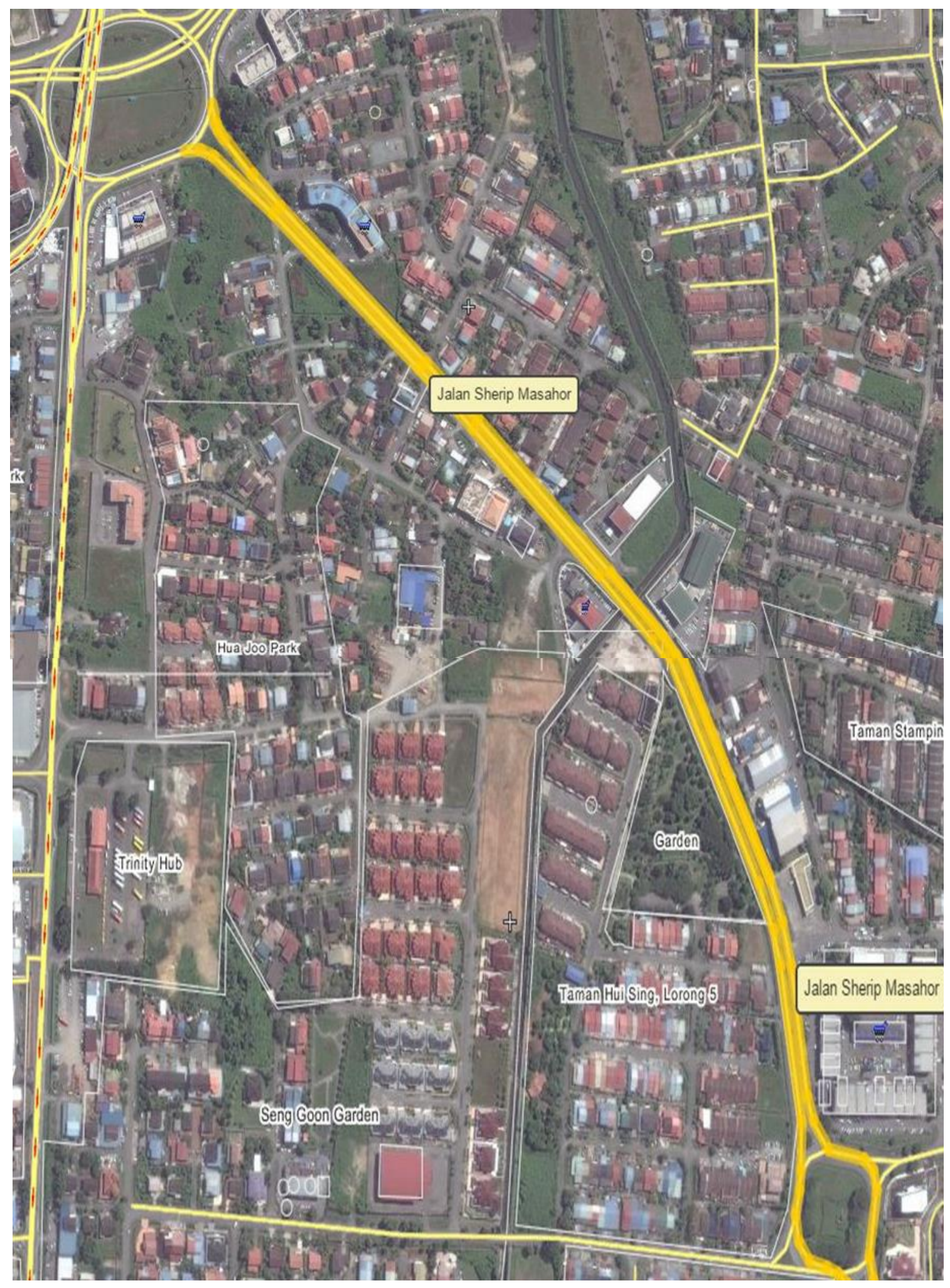

Figure 6. Aerial View of the Chosen Stretch of Road and Grassed Road Divider (http://www.wikimapia.org) 


\subsection{Digital representation}

The digital platform chosen was Storm Water Management Model (SWMM), a simulation software for runoff conveyance in developed areas [12-13]. The runoff element of SWMM works on a group of subcatchment areas that collect stormwater and create stormwater runoff. The convey system of SWMM transfers this runoff through a network of channels, pipes, pumps, storage devices, and regulators. Information such as flow rate and flow depth in each channel and pipe, and the quantity of runoff produced in each subcatchment would be obtained from the simulation. Listed below are some of the design criteria of a bio-retention system.

\subsection{Specification}

Referring to Table 1 that shows the specification of a bio-retention system, the length to width ratio for designing a bio-retention system is 1:2 under the recommendation of Malaysian Urban Stormwater Management Manual. Therefore, a single unit of bio-retention system was designed to $3 \mathrm{~m}$ $\times 6 \mathrm{~m}$ in size. Due to the chosen road stretch consisted of two-way lanes, the width was assumed half for one lane and another half for the opposite lane. The size adopted for SWMM modelling was $1.5 \mathrm{~m} \times$ $6 \mathrm{~m}$ instead.

Table 1. Physical specification and geometry of a bio-retention system [8]

\begin{tabular}{|l|c|}
\hline Parameter & Specification \\
\hline Minimum Size & $3 \mathrm{~m}$ wide by $6 \mathrm{~m}$ long \\
\hline Length and Width ratio & $2: 1$ \\
\hline Maximum Emptying Time & $\leq 24 \mathrm{hours}$ \\
\hline Permeability of Planting Bed & $\geq 13 \mathrm{~mm} / \mathrm{hr}$ \\
\hline Ponding Depth & $150 \mathrm{~mm}-300 \mathrm{~mm}$ \\
\hline Depth of Groundwater Table (below drainage layer) & $0.60 \mathrm{~m}(\mathrm{~min})$ \\
\hline
\end{tabular}

\subsection{Soil types}

Choosing the suitable soil types is important to provide nutrients and water to support plant life in a bio-retention system. Correct soils would improve the infiltration rates of the surface runoff discharged to the system, control the infiltration rates for the pollutant removal purposes, and support plant growth and long-term health.

According to [14], sandy loam, loamy sand, or loam texture were recommended for bio-retention systems. Based on water balance computations done in his study, for bio-retention systems, soils with rates of infiltration higher than $0.5 \mathrm{in} / \mathrm{hr}$ were preferred. Minimum infiltration rates for loamy sand, sandy loam, and loam soils were ranging from $0.52 \mathrm{in} / \mathrm{hr}$ to $2.41 \mathrm{in} / \mathrm{hr}$. Loamy soils such as silt loams, and sandy clay loams with rates of infiltration equaled to or lower than $0.27 \mathrm{in} / \mathrm{hr}$ were not suitable to be used. Mentioned in [8], the soil content should compose of $15 \%$ organic matter and clay content less than $25 \%$ for the optimum performance of the system.

Table 2 shows the characteristics of sand, loamy sand, sandy loam and loam that include hydraulic conductivity, suction head, porosity, field capacity and wilting point needed to be used in modelling. 
Table 2. Characteristics of sand, loamy sand, sandy loam and loam [15]

\begin{tabular}{|l|c|c|c|c|c|}
\hline \multicolumn{1}{|c|}{$\begin{array}{c}\text { Soil Texture } \\
\text { Class }\end{array}$} & $\begin{array}{c}\text { Hydraulic } \\
\text { Conductivity, } \\
\text { K (in/hr) }\end{array}$ & $\begin{array}{c}\text { Suction } \\
\text { head, } \boldsymbol{\Psi} \\
\text { (in) }\end{array}$ & Porosity, $\boldsymbol{\phi}$ & $\begin{array}{c}\text { Field } \\
\text { Capacity }\end{array}$ & $\begin{array}{c}\text { Wilting } \\
\text { Point }\end{array}$ \\
\hline Sand & 4.74 & 1.93 & 0.437 & 0.062 & 0.024 \\
\hline Loamy Sand & 1.18 & 2.40 & 0.437 & 0.105 & 0.047 \\
\hline Sandy Loam & 0.43 & 4.33 & 0.453 & 0.190 & 0.085 \\
\hline Loam & 0.13 & 3.50 & 0.463 & 0.232 & 0.116 \\
\hline
\end{tabular}

\subsection{Design rainfall}

Design rainfall is important to produce satisfactory drainage and stormwater management design. Average Recurrence Interval (ARI) is the average length of time between rainfall events that have the same volume and duration. Most structures including urban drainage systems have been designed for flood with average ARIs from 2 to 50 years where 10 years is the common value. In this paper, for roads, ARIs of 2, 5, and 10 years were chosen for designing the facility. Rainfall duration of 60 minutes was used in finding the rainfall depth for respective ARI that could representing typical cumulus storms in equatorial regions. The design rainfall was calculated using Polynomial Approximation Method complying to recommendation in [8].

\subsection{Road surface runoff}

Due to relative smaller road surface areas (less than 80 ha for a single catchment), road surface runoffs were calculated using Rational Method [8].

\section{Results and discussion}

Two SWMM models were created for the investigations on with and without bio-retention systems. Model without bio-retention system represented the existing conditions (see Figure 7). Another model was a "whaf if" scenario when the grassed road divider was modified to become bio-retention cell (see Figure 8).

Referring to the top right corner of Figure 7, the modelling approach adopted for scenario without bio-retention system was:

a) Rainfall (R1) was intercepted by road catchment and grassed road divider;

b) Road surface (S1) was 100\% impervious, therefore $100 \%$ of the rainfall was converted to runoff;

c) Grassed road divider (S2) was made to have low infiltration rate $(0.25 \mathrm{in} / \mathrm{hr})$ so that $90 \%$ of the rainfall was converted to runoff;

d) Road runoffs were drained to the roadside drain $(\mathrm{C} 1-\mathrm{C} 2)$ and flowed downstream to an exit point (O1); and

e) Road gutter was represented by J1 (see Figure 1) and changes of drain slope was represented by $\mathrm{J} 2$.

Rain 


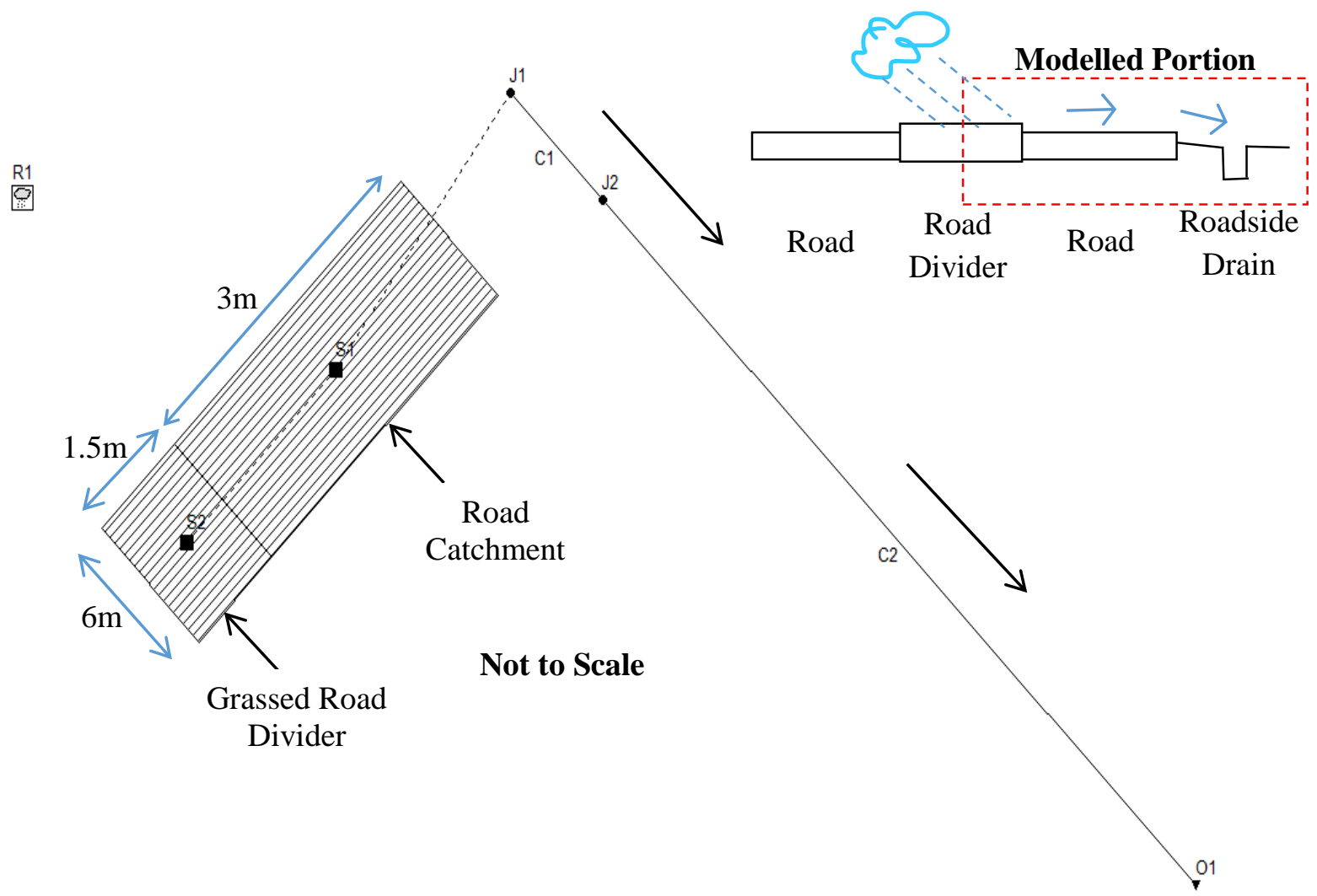

Figure 7. SWMM model of existing condition without bio-retention system

$\mathrm{R} 1$
9

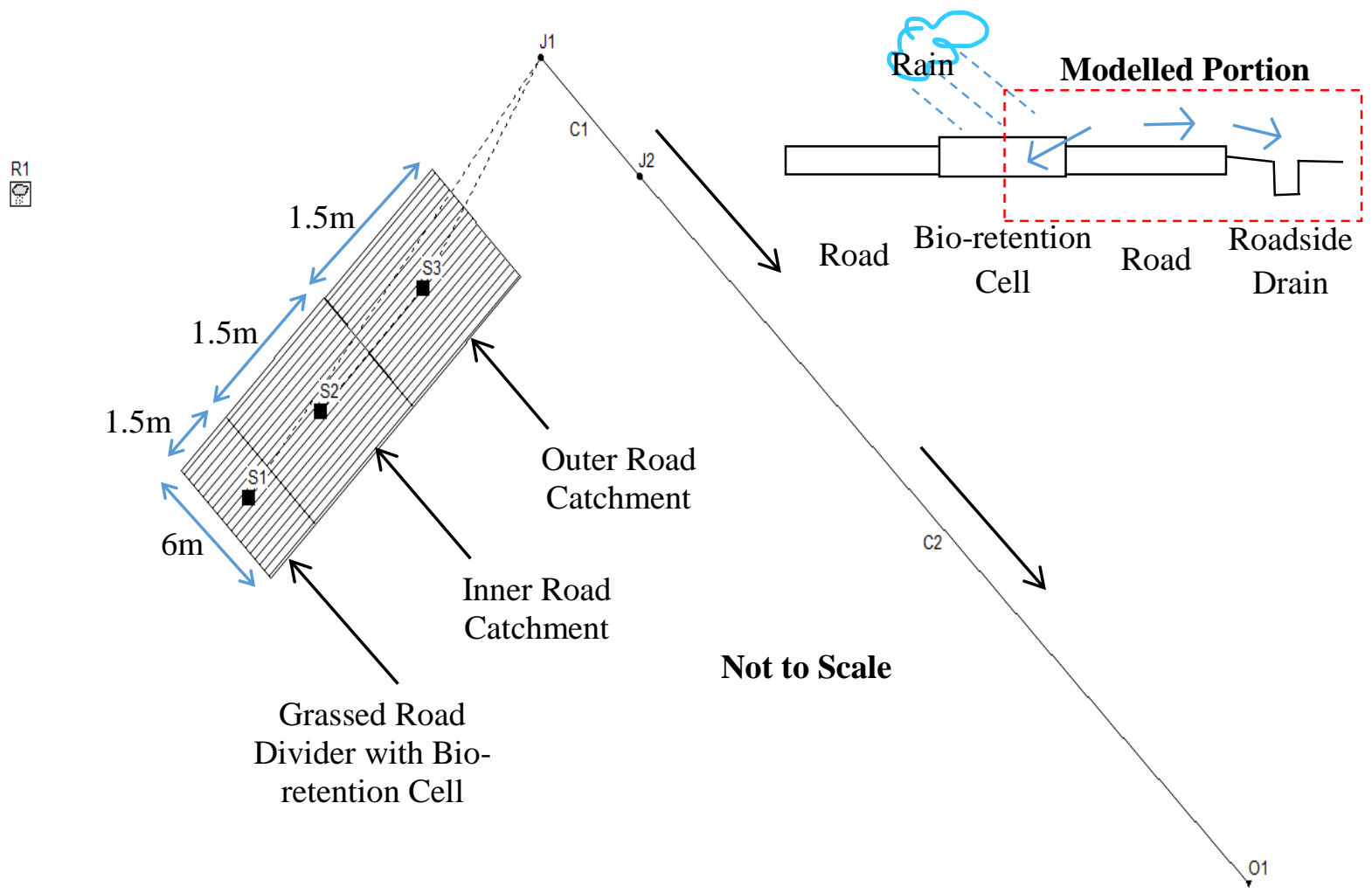

Figure 8. SWMM Model with Bio-retention System Installed on the Road Divider 
Referring to the top right corner of Figure 8, the modelling approach adopted for scenario with bio-retention system was:

a) Rainfall (R1) was intercepted by road catchment and grassed road divider;

b) Grassed road divider (S1) was made to have bio-retention cell of different soil types to infiltrate runoff from road surface;

c) Road surface was $100 \%$ impervious, therefore $100 \%$ of the rainfall was converted to runoff, but the difference with previous scenario, it was separated into inner (S2) and outer (S3) roads;

d) Road runoff from $\mathrm{S} 2$ was first drained to bio-retention system (S1) and once full, the overflow was directed to roadside drain $(\mathrm{C} 1-\mathrm{C} 2)$;

e) Road runoff from $\mathrm{S} 3$ was drained to the roadside drain $(\mathrm{C} 1-\mathrm{C} 2)$ and together with overflow from $\mathrm{S} 1$ and $\mathrm{S} 2$, the runoff flowed downstream to an exit point (O1); and

f) Road gutter was represented by J1 and changes of drain slope was represented by J2.

To illustrate the design bio-retention cell in item (b) above, ponding depth (see Figure 3) was set to $150 \mathrm{~mm}$ that could be achieved by placing normal road curb at the road edge. The soil/storage depth was set to $600 \mathrm{~mm}$ according to normal practice. Different soil types and their characteristics outlined in Table 2 were inserted to the SWMM model.

Outcomes of the two modelling approaches above were tabulated in Table 3. Columns 1-3 were the design hydrological data according to 2-, 5- and 10-year ARIs. Column 4 depicted the total generated runoff rate gathered at point O1. As ARIs increased, the resultant rainfall intensities and generated runoffs also increased.

If the ARIs were to increase to 20-, 50- and 100-year, the generated runoffs would increase proportionally; and the direct implications were to have larger structure to accommodate the design flows out of these higher ARIs. To have cost-effective structure, the normal practice is to design to 10year ARI. Lower ARIs (2- and 5-year) are relevance because the data are representing lesser rains and such rain events are expected to occur more often than the 10-year ARI rains.

Table 3. Results of runoff data with and without bio-retention systems

\begin{tabular}{|c|c|c|c|c|c|c|c|}
\hline \multirow[t]{2}{*}{$\begin{array}{c}(1) \\
\text { ARI } \\
\text { (year) }\end{array}$} & \multirow{2}{*}{$\begin{array}{c}\text { (2) } \\
\text { Storm } \\
\text { Duration } \\
\text { (minutes) }\end{array}$} & \multirow{2}{*}{$\begin{array}{l}(3) \\
\text { Rainfall } \\
\text { Intensity } \\
(\mathrm{mm} / \mathrm{hr})\end{array}$} & $\begin{array}{l}\text { (4) } \\
\text { Without } \\
\text { Bio- }\end{array}$ & \multicolumn{4}{|c|}{$\begin{array}{c}\text { (5) } \\
\text { With Bio-Retention } \\
\text { Runoff After Infiltrating Soil Types }\left(\mathrm{m}^{3} / \mathrm{s}\right)\end{array}$} \\
\hline & & & $\begin{array}{c}\text { Runoff } \\
\left(\mathrm{m}^{3} / \mathrm{s}\right)\end{array}$ & Sand & $\begin{array}{c}\text { Loamy } \\
\text { Sand }\end{array}$ & $\begin{array}{l}\text { Sandy } \\
\text { Loam }\end{array}$ & Loam \\
\hline 2 & 60 & 71.71 & 0.000422 & 0.0002104 & 0.0002107 & 0.0002108 & 0.0002109 \\
\hline 5 & 60 & 89.57 & 0.000542 & 0.0002939 & 0.0002943 & 0.0002944 & 0.0002945 \\
\hline 10 & 60 & 101.29 & 0.000622 & 0.0003521 & 0.0003525 & 0.0003527 & 0.0003527 \\
\hline
\end{tabular}

Both modelling approaches shared the same design hydrological data in columns 1-3. Runoff data gathered at exit point $\mathrm{O} 1$ after infiltrating bio-retention systems were tabulated in column 5. Sand was included along with loamy sand, sandy loam and loam. Sand had the highest void in between sand particles; while the rest of soil types had comparatively lower void due to the presence of clay and nutrients. It was used as a control for comparison with the three soil types.

Comparing columns 4 and 5 in Table 3, the reduced runoffs were in the range of 50\% to $43 \%$ (see Figure 9). 2-year ARI had comparatively highest runoff reduced, while 10-year ARI had lower reduction in runoff. Despite so, all estimated reductions were less than 10\%. Authors deduced that the soil types had similar bio-retention capability when subjected to 60 minutes of varying rain intensities. 
From the analysis, extrapolating the graph to higher ARIs, for example 20-year ARI and above, the extends of runoff reduced could be well below $40 \%$. Therefore, any system above 10-year ARI could be rendered as ineffective. In contrast, for events below 10-year ARI, the runoffs being reduced would increase. Thus, it was suggesting that the design bio-retention systems with any of the soil types could withstand 60 minutes, 10-year ARI and below rain events.

Another finding from the analysis suggested that roadside drain was necessary for rainfall patterns in the equatorial regions. Removing roadside drain was unwise against high rainfall and runoff. Furthermore, by adding bio-retention system, parts of flow and dust/soil particles from roads could be absorbed by the bio-retention system. Design of roadside drain could be reduced to save costs of construction and maintenance.

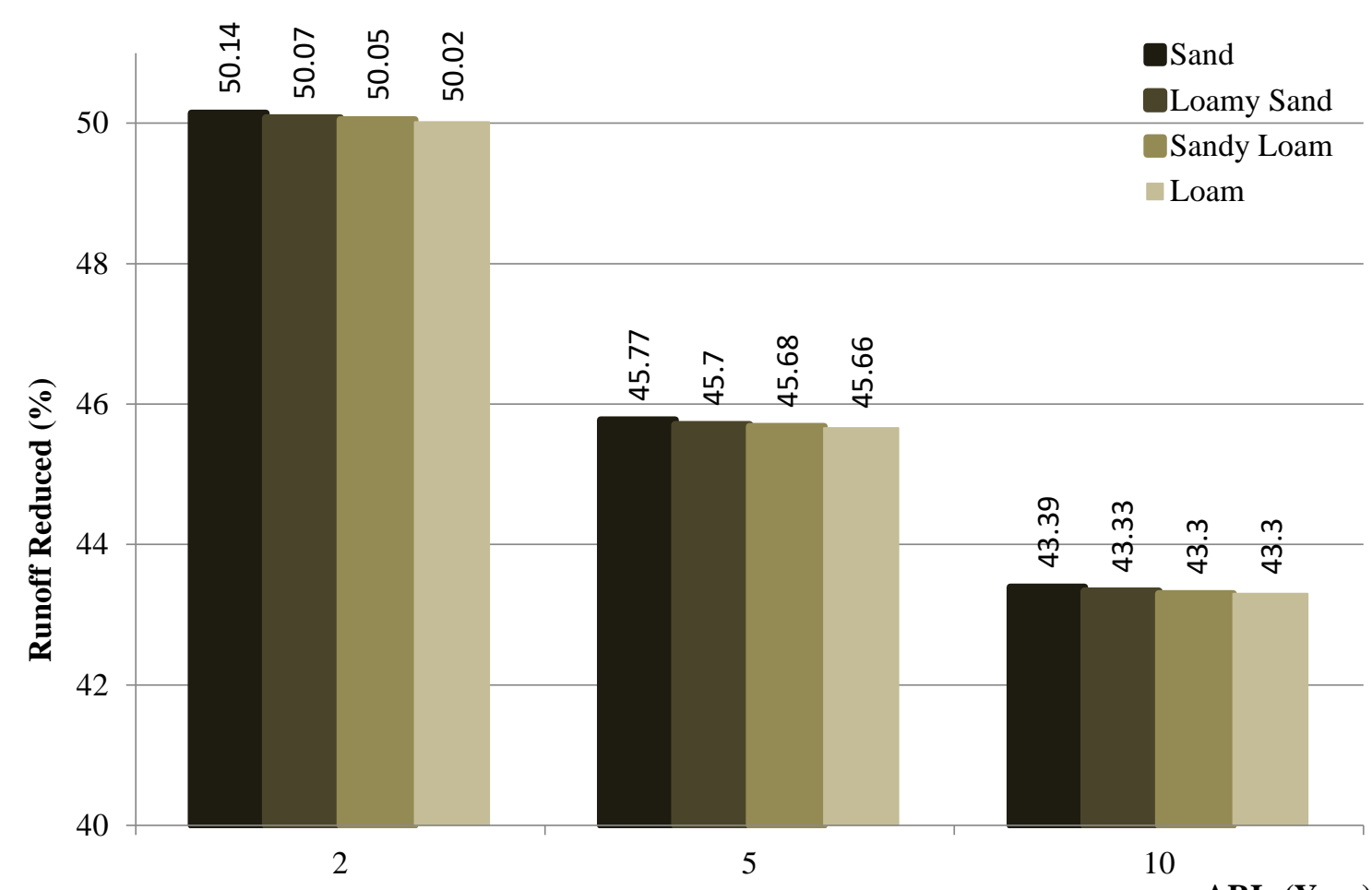

Figure 9. Performance of bio-retention systems under different ARIs

\section{Conclusion}

In conclusion, road runoff could be reduced effectively when adopting bio-retention system in grassed road divider. Bio-retention system could function to infiltrate and store water within its system. $40-50 \%$ of runoff reduction was estimated from a design of $150 \mathrm{~mm}$ ponding depth and $600 \mathrm{~mm}$ soil/storage depth. Soil types of loamy sand, sandy loam and loam would give similar water retention capability.

The investigations on bio-retention system were carried out by developing stormwater conveyance models using USEPA SWMM 5.1. Two models were created for road drainage scenarios with and without bio-retention systems. By using a case study, existing site conditions at the site could be imitated. A realistic bio-retention system subjected to 60 minutes equatorial rains of 2-, 5- and 10year ARIs had been simulated for discussion. 


\section{Acknowledgement}

This research was funded by the Special Grant Scheme F02/SpGS/1405/16/6 rendered by Universiti Malaysia Sarawak.

\section{References}

[1] Fanellli, R., Prestegaard, K. and Palmer, M. (2017). Evaluation of Infiltration-Based Stormwater Management to Restore Hydrological Processes in Urban Headwater Streams, Hydrological Processes, Vol. 31, No. 19, 3306-3319.

[2] Shafique, M. (2016). A Review of the Bioretention System for Sustainable Storm Water Management in Urban Areas, Materials and Geoenvironment, Vol. 63, No. 4, 227-236.

[3] Park, M., Lee, J., Park, B. and Kim, S. (2015). Estimation of Bio-Retention Design Capacity Using Principal of Diminishing Returns, Journal of Korea Society of Hazard Mitigation, Vol. 15, No. 2, 363-368.

[4] City of Raleigh (2018). Lower Audubon Drive Storm Drainage Improvements, Retrieved from https://www.raleighnc.gov/home/content/PWksStormwater/Articles/AudubonDriveStormwaterImprovemen ts.html [Accessed 27 March 2018].

[5] Department of Irrigation and Drainage Malaysia (2012). Urban Stormwater Management Manual for Malaysia, $2^{\text {nd }}$ Edition, Percetakan Nasional Berhad, Malaysia.

[6] Roy-Poirier, A., Champagne, P. and Filion, Y. (2010). Bio-Retention Processes for Phosphorus Pollution Control, Environmental Reviews, Vol. 18, 159-173.

[7] Liu, J., Sample, D.J., Bell, C. and Guan Y. (2014). Review and Research Needs of Bioretention Used for the Treatment of Urban Stormwater, Water, Vol. 6, No. 4, 1069-1099.

[8] Li, Z.Y. and Lam, K.M. (2015). Statistical Evaluation of Bio-Retention System for Hydrological Performance, Water Science and Technology, Vol. 71, No. 11, 1-9.

[9] Mikovits, C., Rauch, W. and Kleidorfer, M. (2014). Dynamics in Urban Development, Population Growth and their Influences on Urban Water Infrastructure, Procedia Engineering, Vol. 70, 1147-1156.

[10] Zhang, S. and Guo, Y. (2013). Stormwater Capture Efficiency of Bio-Retention Systems, Water Resources Management, Vol. 28, No. 1, 149-168.

[11] Jabatan Kerja Raya Malaysia (1986). A Guide on Geometric Design of Roads, JKR Malaysia.

[12] Rossman, L.A. (2010). Storm Water Management Model User's Manual Version 5.1, US Environmental Protection Agency.

[13] Masi, M. (2012). A SWMM-5 Model of a Denitrifying Bioretention System to Estimate Nitrogen Removal from Stormwater Runoff, ISBN 1249846684, ProQuest \& UMI Dissertation Publishing.

[14] James, W. (1994). Current Practices in Modelling the Management of Stormwater Impacts, ISBN 1566700523, CRC Press.

[15] Rawls, W., Brakensiek, D. and Miller, N. (1983). Green-Ampt Infiltration Parameters from Soil Data, Journal of Hydraulic Engineering, Vol. 109, No. 1, 62-70. 